\title{
Registration and Assessment of Load Cycles in Pipelines
}

\author{
O. Torop a and V. Schmidt \\ ${ }^{a}$ RWTH Aachen, Aachen, Germany \\ b TÜV Rheinland Industrie Service GmbH, Cologne, Germany
}

УдК 539.4

\section{Регистрация и оценка циклов нагружения в трубопроводах}

\author{
О. Тороп ${ }^{\mathrm{a}}$, В. Шмидт \\ a Университет Земли Рейи-Вестфалия, Аахен, Германия \\ ${ }^{\sigma}$ ТЮФ Рейнланд Индастри Сервис ГмбХ, Кельн, Германия
}

Разработан оптимизированньй метод регистрации и оченки циклов нагружения, основанньй на анализе результатов усталостньх испьттаний образцов в виде арки. Нспьттания проводили при постоянньх (по типу построения усталостных кривьх) и переменных амплитудах циклических напряжений. Выполнень конечноэлементные расчеть, позволяющие оценить уровень систематических и случайных погрешностей, что обусловлено используемьли схемами усталостных испьтаний и геометрией образцов.

Ключевые слова: усталостные испытания, цикл нагружения, циклические напряжения, конечноэлементный расчет.

Introduction. For the fatigue strength calculation of existing defects the knowledge of the dynamic stress of internal pressure is required. The fault estimation methods used during calculation are mostly based on tests in which the failure occurred under Wöhler loading conditions [1-3]. Therefore it was necessary to convert the occurring quasi-stochastic dynamic internal pressure loading into the Wöhler one with equivalent damage impact. For this simple and conservative load cycle counting methods were used previously [4-7].

In some cases, the conservative approach results in disproportional high increase in maintenance costs. The reason is that more and more faults are detected with increasing operation period and that the integral dynamic damage increases since startup. Therefore, there is a necessity to replace the more conservative load cycle registration and evaluation methods with advanced methods which express the actual damage due to dynamic internal pressure loading. Since the degree of conservativeness of single load cycle registration and evaluation methods depends on the component form, the type of loading and the form of loading, the planned realization of measurements was secured by experimental examination. The test scheme was planned and executed by TÜV Rheinland in collaboration with the laboratory of Lightweight Design of RWTH Aachen. 
Experimental Set-Up. The basic material for manufacturing of specimens was taken in the form of five half-shell segments of longitudinally welded pipes. Standard shape geometry for all test specimens (Fig. 1) was defined in collaboration with TÜV. Referring to the primary test results, further processing was provided for the weld region.

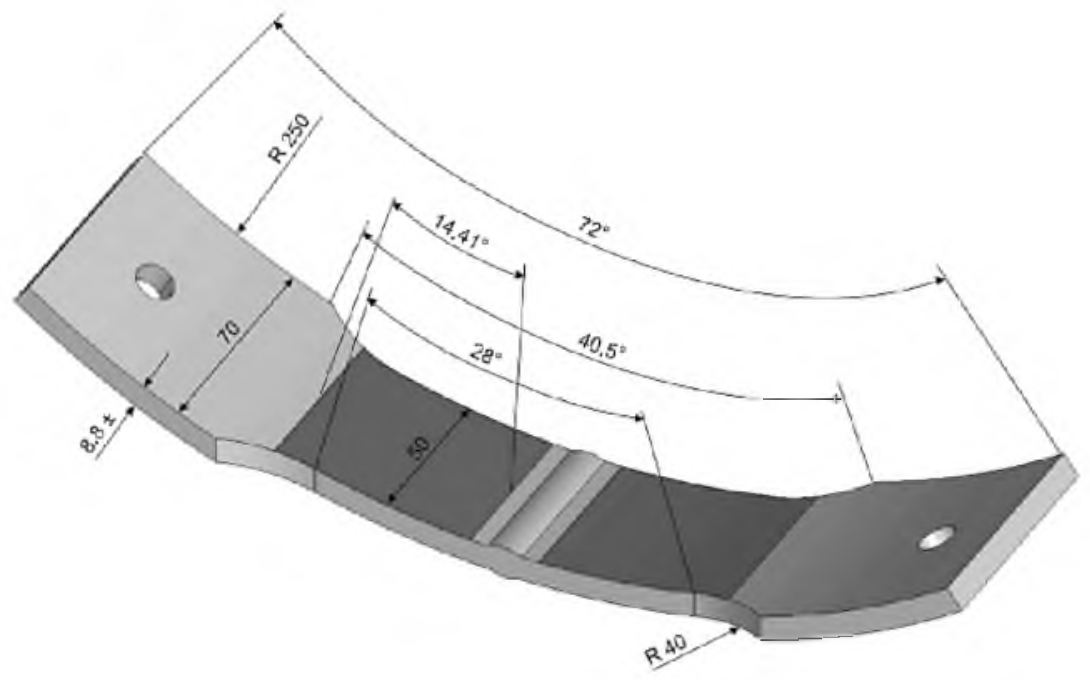

Fig. 1. Specimen geometry.

Comparability of the test series with specimen from different pipes was achieved by artificially inserting of notch-like defects, which ensured identical defect geometry.

Finally, five specimen forms were developed:

1. Unprocessed in the weld seam region specimen.

2. Removal of the weld reinforcement from both weld passes, milled flat transverse notch at the weld pass inside, centered grooving on the weld pass inside.

3. Removal of the weld reinforcement from both weld passes, milled flat transverse notches at both weld passes, centered grooving inside and outside.

4. Removal of the weld reinforcement from both weld passes, centered recess (reduction on the outer weld pass diameter).

5. Removal of the weld reinforcement from both weld passes, symmetrical flat gauges in the weld region.

On the basis of the shape geometries defined for all specimens, test equipment (Fig. 2) was designed to induce cyclic circumferential tension stresses initiated by compressive forces on the pipe segment specimen.

The upper region of the testing equipment contained the load cell and the hydraulic cylinder. In the lower part, the specimen carrier was assembled. The force transmission was carried out by a pressure rod which transfered the force to the specimen through two flexible pressure stamps as an equivalent to the internal pressure load in pipelines.

The strain gauges were applied to both sides of the outer weld passes for the collection of circumferential strains in the region of tension pulsating stress for all specimens. 


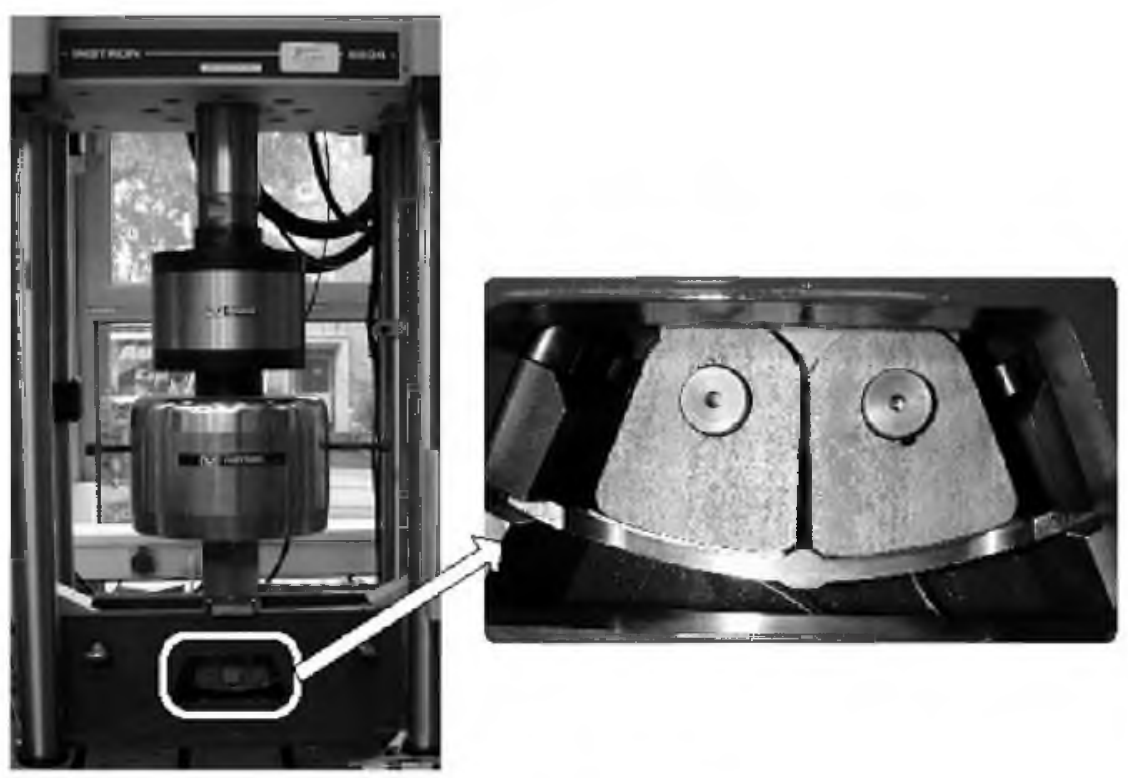

Fig. 2. Loading equipment.

Lead bands with different thicknesses and forms were introduced in order to level out the irregularities of inner surfaces of the specimens.

The testing plan regarding the loading level, kind of loading, loading duration and specimen geometry was established successively on the basis of results from the former tests. The initial situation was to load the specimens by uniform tension cyclic forces or Wöhler loading. The maximum and minimum stresses of the uniform loading, as well as loading duration were different for each specimen form.

Based on the characteristic pipeline pressure curves, TÜV generated the equivalent artificial loading, or transient loading, which also was introduced in the specimens as strain-controlled loading [9-12].

The experimental data were handed in by the Institute of Lightweight Design RWTH Aachen in form of data tables, which contained data for strain gauges, measured force and position.

Evaluation of Experimental Results. In the first step, during a load cycle collection the preliminary data processing was performed in order to collect load alterations. This was done by means of different counting methods:

(i) range counting method;

(ii) level crossing method [13];

(iii) Rainflow method.

In the next step, during the load cycle evaluation the registered load alterations with different oscillation amplitudes were converted into uniform load alterations. According to the theory on which the calculation was based, the uniform load alterations cause the same fatigue of a structural component as the actual load alterations with different oscillation amplitudes.

The damage effects of individual load cycles with different amplitudes were determined by means of the Palmgren-Miner rule in combination with different mean stress correction methods (Gerber, Goodman). 
The results of the Wöhler tests with unmachined weld seam and 2-notch specimen are shown in Fig. 3. Here the stress range normalized with respect to tensile strength (loading rate KB) versus the number of cycles to failure is shown. Both axes have logarithmic scales. The Wöhler lines for SAW- and seamless-pipes that correspond to DIN 2413 [8] are additionally shown in normalized form. They were used as a reference during life time analysis for pipes which meet the acceptance specification. The right part of diagrams contains the experimental results for the unmachined weld seam in form of colored circles. Other points that are located lower and depicted in form of colored triangles represent the experimental results which are corrected with respect to the bending stresses.

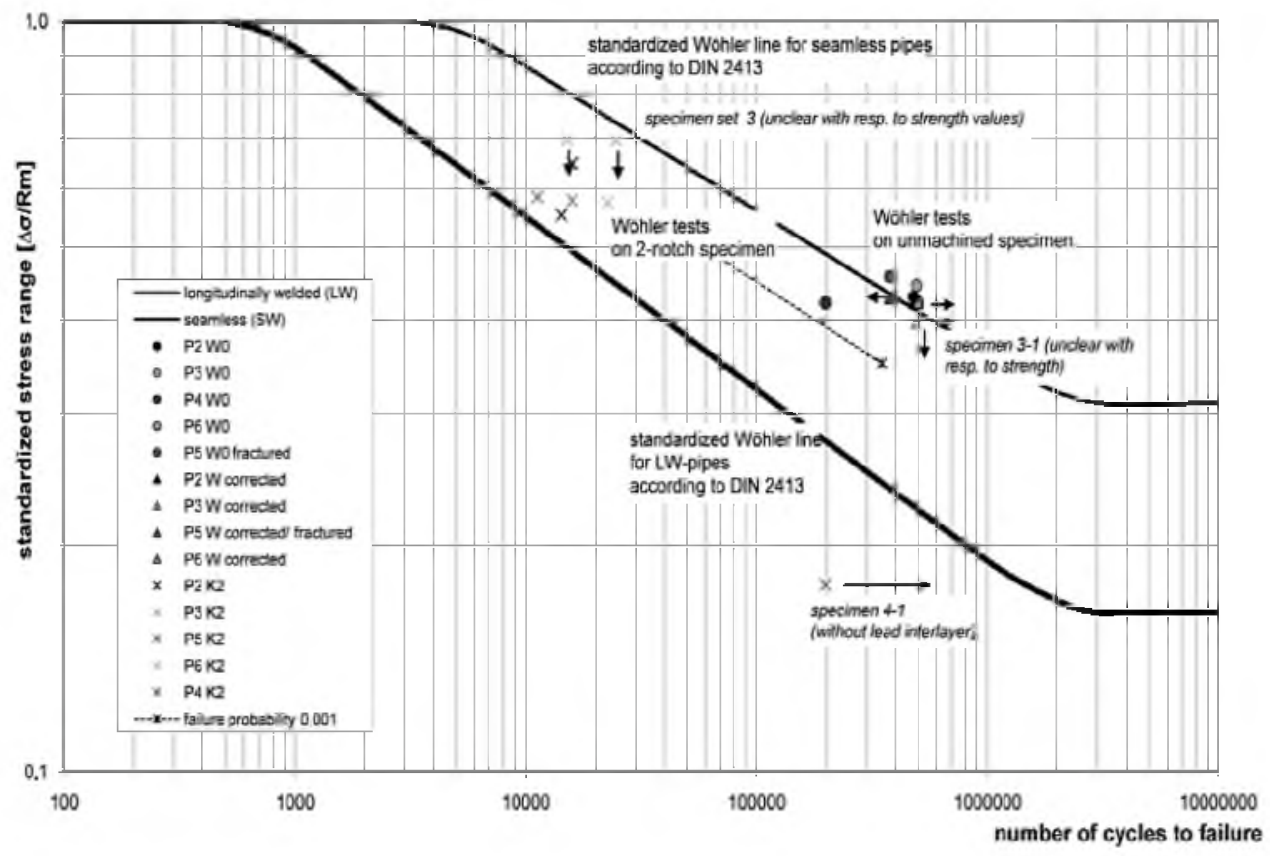

Fig. 3. Standardized fatigue strength: Wöhler tests on the unmachined weld seam and 2-notch specimen.

It appeared that all experimental results for unmachined specimens are located approximately in the region of the Wöhler line for seamless pipes.

Even considering a very small segment on the lower border of the failure probability distribution $(99.9 \%$ probability of life time extension shown by dashed line) the calculation basis appears to be improved by a factor of 4 in comparison to Wöhler lines given in DIN 2413 for SAW-pipes because of the logarithmic scale.

The knowledge about the optimal load cycle counting and analysis methods for transient loadings was obtained from the tests on identical 2-notch specimens subjected to different loadings. The Wöhler tests with 2-notch specimen are depicted in Fig. 4. The stress range standardized with respect to the tensile strength $\mathrm{KB})$ is displayed versus the number of cycles to failure. Additionally, Fig. 4 contains the results of the transient tests. The transient test results are plotted with three different symbol types. 


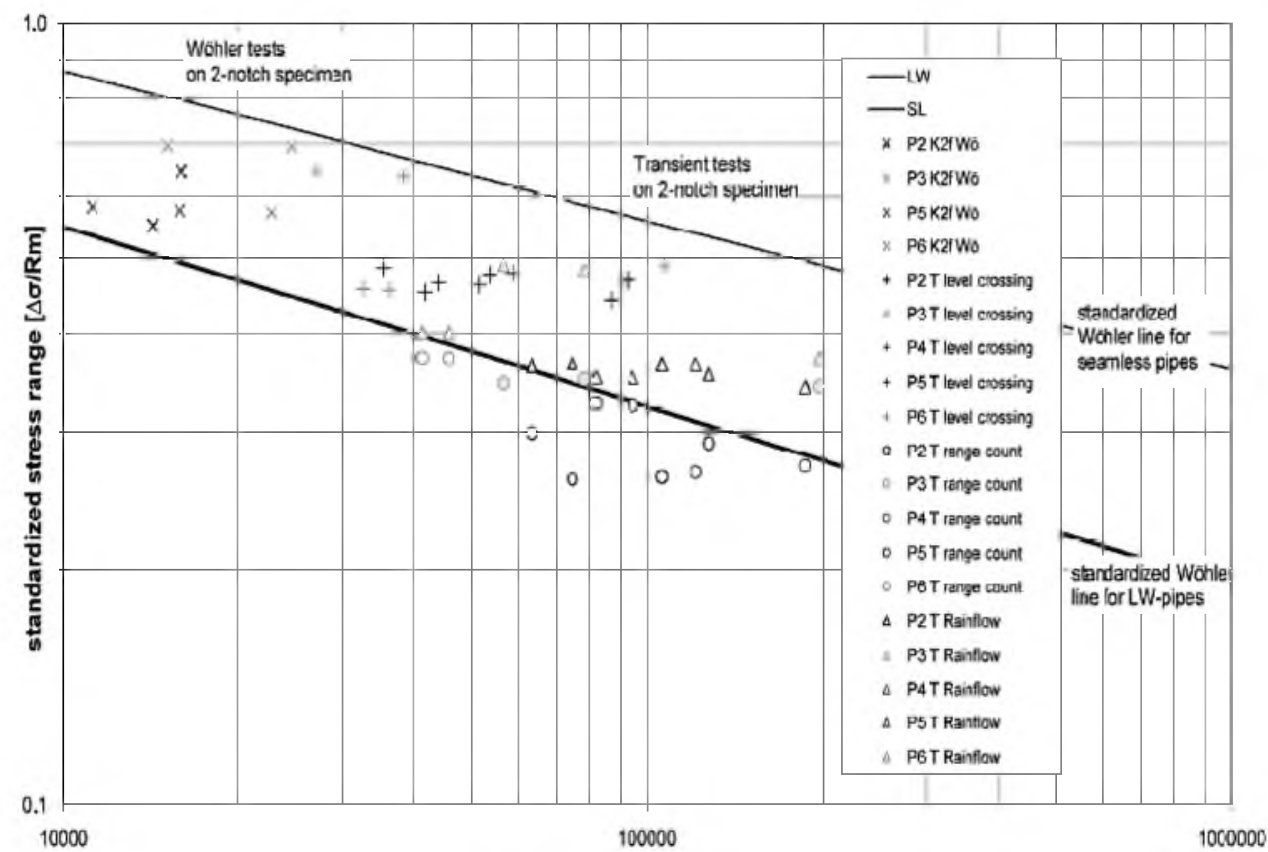

Fig. 4. Standardized cyclic strength: Wöhler and transient tests on specimen with 2-notch geometry (hinged stamp adjustment): $(O)$ evaluation with range counting method, $(+)$ evaluation with level crossing method, $(\triangle)$ evaluation with Rainflow method.

The diagram shows that we get the lowest damage by using the analysis with the range counting method and the highest with the level crossing method. The experimental results evaluated with the Rainflow method show the same number of cycles to failure as the range counting method. On the other hand, the analysis with the level crossing method results in known reduction of load cycle numbers with a simultaneous increase in amplitude.

Figure 5 shows the experimental results of all 2-notch specimens in a standardized form separately for different analysis methods applied. The Wöhler tests on 2-notch specimen are shown as reference in the top lines. The result of the specimen 3-1 lies a little above the other results although this value cannot be excluded as an outlier. Together with the data points the mean value of all data are plotted in form of crosses.

The results for the range counting depicted in the lowest "line 1" clearly show that this approach generally predicts too small damage and therefore this method is unsafe. The results of transients evaluated with the level crossing method are presented in the "line 2." They are located above the results of the corresponding Wöhler tests in "line 4" and show the conservativeness of the method which was theoretically expected. The mean values of the Wöhler tests without specimen 3-1 yields on average a $15 \%$ more conservative damage prognosis for the transient loads used for the experiment.

The results for all transients evaluated with the Rainflow method are presented in "line 3." The mean value of the experimental points is congruent with the mean value for the Wöhler tests, especially without the specimen 3-1. Therefore, the rainflow method comes out as the most optimal. 


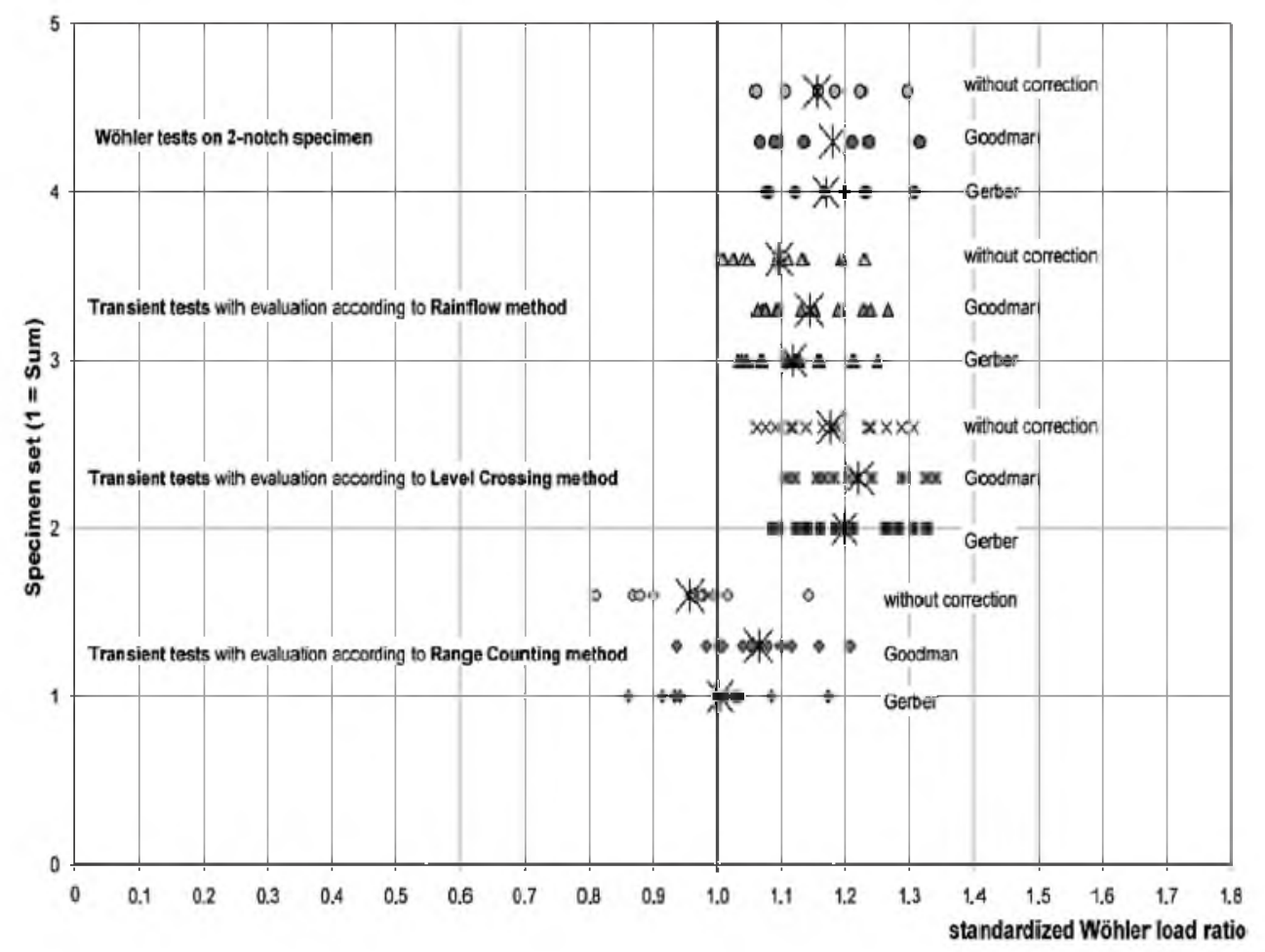

Fig. 5. Standardized Wöhler loading (classificated by load acquisition method): Wöhler and transient tests on specimen with 2-notch geometry.

Numerical Implementation. The experiments described above were not carried out under optimal conditions. After the event it turned out that the ovality and curvatures of the specimens were not measured. To evaluate the influence of these factors and to estimate the errors a finite elements (FE) analysis was performed by means of ANSYS 10.0. Additionally the influence of bending stresses on the evaluation of a life time was derived.

In the first step, the simulation model of the unmachined weld seam specimen for the ideal state was developed. The $3-\mathrm{D}$ view of a simulated geometry is shown in Fig. 6.

The following load case was designed:

1. The $80000 \mathrm{kN}$ force was distributed on two lines parallel to the weld seam in the middle of the upper surface of each stamp (54 nodes loaded with 1481,5 kN each).

2. Fixation of the fixation blocks was applied in joint region on lines in all 3 translational directions. Only rotation around $Z$ axis is allowed as depicted in Fig. 6.

3. Contact was defined between stamps and lead bands.

For the developed model, elastic strains in $X$ direction and von Mises equivalent stresses were evaluated. The evaluation results are shown in Fig. 7. As expected, the highest stresses occurred close to the middle of the specimen. In the center of the weld seam region the stresses were smaller because of the different wall thicknesses. The change of both thickness and the Young modulus on the 
border between the weld region and the specimen caused an offset in strains. For the geometry transition we obtained a high offset in strains at the corner where the pipe was connected to the fixation block, denoted as MX in Fig. 7.

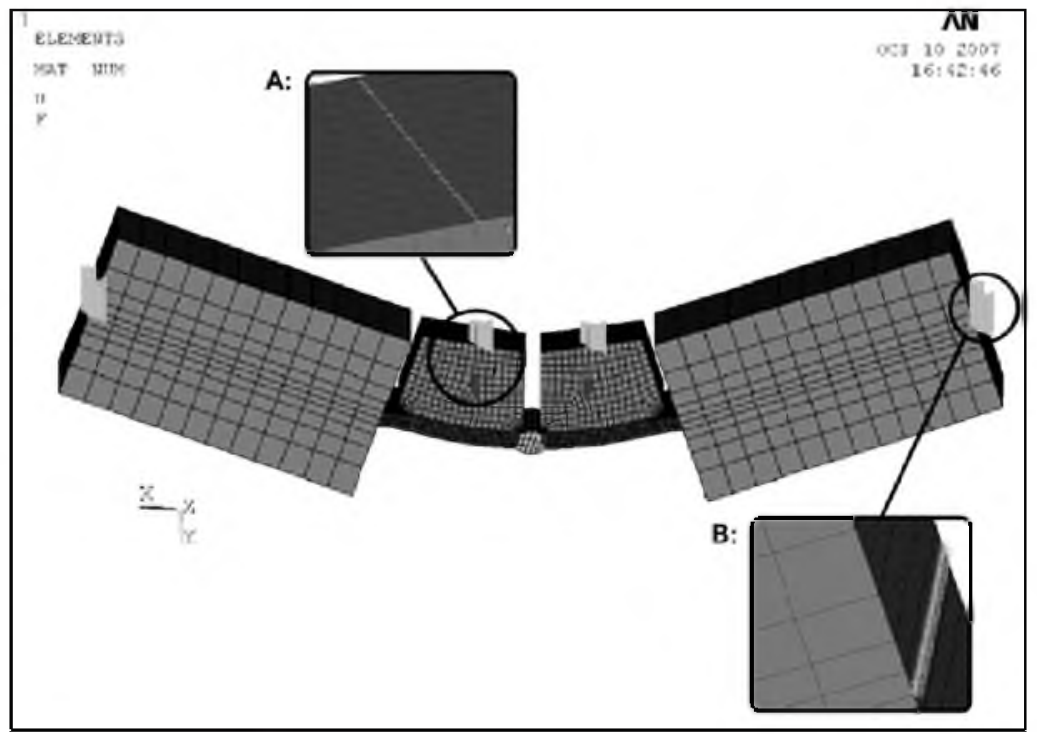

Fig. 6. Meshed 3-D model with applied loading.

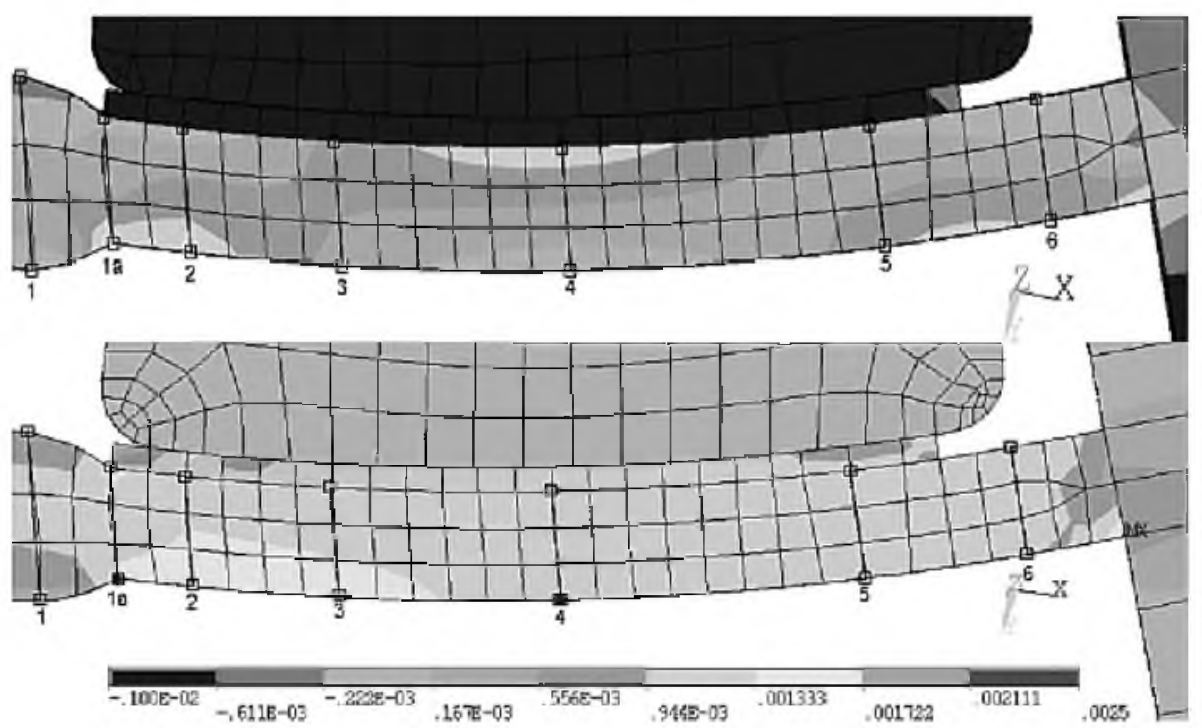

Fig. 7. Distribution of strains in $X$ direction and von Mises equivalent stresses.

Additional simulations showed that the biggest displacements occurred near the center of the seam weld in the region of force transmission. For the model with the pipe radius smaller than stamp radius the contact between the stamp and the lead interlayer occurred in 2 lines exactly on the borders of the power piston. This was the reason why the load transmission went through these regions and caused high stresses. 
For the simulation model with pipe radius bigger than stamp radius, the stamp was in contact with the lead interlayer in only one line in the middle causing big stresses in the region of force transmission.

Additionally, a specimen with double-notched weld seam was simulated. It appeared that in the notch region a typical notch stress distribution occurred with the highest offset of stresses at the tip of the notch. The notches were added specifically to allow the breakage in the middle of the specimen.

In order to investigate the influence of the pipe thickness on the experiment, a specimen with different thicknesses on the right and left side of the weld was modeled. As expected, the stress distribution was not symmetric.

Conclusions. An optimized load cycle registration and assessment method which enables an improved fitness-for-service assessment and yields a higher residual service life was developed on the basis of fatigue test series with arched test pieces. The results of these tests lead to the following improvements:

as the experimental results for unmachined specimens lie approximately in the region of the Wöhler line for seamless pipes the calculation basis was improved by a factor of 4 in comparison to Wöhler lines given in DIN 2413 for SAW-pipes;

usage of the 2-notch geometry in the specimen form reduced the experimental running time approximately ten times.

The results for range counting showed that this approach generally predicts too small damage and is to be considered as unsafe. The results of level crossing counting were located above the results of the corresponding Wöhler tests and showed the conservativeness of the method. For the Rainflow counting the mean value of the experimental points was almost congruent with the mean value for the Wöhler tests. Therefore, the Rainflow method is an optimal analysis method since it considers the fatigue strength of defects in most accurate way.

Additional FE-simulations enabled the verification of systematical errors caused by the chosen test setup and the geometry of the test specimen. They also helped to estimate the random errors caused by irregular geometries of the test specimens, such as misalignment at seams and non circularity. Due to FE simulation results we can come to the following conclusions:

The fact that every specimen has individual curvature affects the experimental results. This leads to the mismatch between the stamp curvature and specimen curvature resulting in different bending stress distribution for each specimen. For example, if the stamp radius is bigger than the specimen radius then the measured bending strains in DMS position is smaller than the actual value. This leads to the unsafe life time estimation.

As all specimens had different thicknesses the influence of thickness was also estimated by means of FE simulations. Results obtained showed that for smaller thickness value we get higher values of stresses and strains in $X$ direction.

\section{Резюме}

Розроблено оптимізований метод реєстрації й оцінки циклів навантаження, який базується на аналізі результатів утомних випробувань зразків у вигляді арки. Випробування проводили за постійних (за типом побудови кривих утоми) та змінних амплітуд циклічних напружень. Виконано скінченноеле- 
ментні розрахунки, що дозволяє оцінити рівень систематичних і випадкових похибок, зумовлених схемами утомних випробувань та геометрією зразків, що використовуються.

1. S. J. Maddox, Fatigue Strength of Welded Structures, Second edition, Abington Publishing (1991).

2. T. P. H. Wirsching, Random Vibrations, Theory and Practice, A WileyInterscience Publication, John Wiley and Sons, Inc. (1995).

3. DIN 45667 (1969).

4. K. T. Endo and H. Nakagawa, "Fatigue of metals subjected to varying stress-prediction of fatigue lives," in: Preliminary Proceedings of the ChugokuShikoku District Meeting [in Japanese], The Japan Society of Mechanical Engineers, (1967), pp. 41-44.

5. J. B. de Jonge, "The analysis of load-time-histories by means of counting methods," National Aerospace Laboratory NRL, MP 82039 U, ICAF Document (1982).

6. N. E. Dowling, "Fatigue predictions for complicated stress-strain histories," J. Mater., 7, 71-87 (1972).

7. I. Rychlik, Statistical Wave Analysis with Application to Fatigue, Ph.D. Thesis, Department of Mathematical Statistics, Lund University (1986).

8. DIN 2413, Berechnung der Wanddicke von Stahlrohren gegen Innendruck (1993).

9. AD-Merkblatt S2, Berechnung auf Wechselbeanspruchung (1998).

10. EN 10208-2, Steel Pipes for Pipelines for Combustible Fluids - Technical Delivery Conditions, Part 2: Pipes of Requirement Class B, June 1996, ANSYS documentation, 2007.

11. E. Haibach, Betriebsfestigkeit. Verfahren und Daten zur Bauteilberechnung, Springer-Verlag (2002).

12. M. Siebel, E. Stieler, Ungleichförmige Spannungsverteilung bei schwingender Beanspruchungen, Volume 7 (1968).

13. FKM-Richtlinie, Rechnerischer Festigkeitsnachweis für Maschinenbauteile aus Stahl, Eisenguß- und Aluminiumwerkstoffen,VDMA-Verlag (2002). 